\title{
Students win pay rise in Michigan strike
}

[WASHINGTON] The University of Michigan, where graduate students have been on strike for the past two weeks in protest over payments for teaching undergraduate courses, has agreed to increase such rates by 10.5 per cent over three years.

But still undecided is the issue of compensation for foreign teaching assistants and the English language courses they are required to take. The strike organizers say the dispute is part of an escalating movement among graduate students in universities across the United States.

The strike is the third major revolt by graduate students in recent years. Three years ago, students at Yale University went on strike over the treatment of low-paid campus employees. And last year, student teaching assistants took strike action at all eight campuses of the University of California over the right to form a union.

Most of the Michigan strikers are members of the Graduate Employee Organization, a union affiliated to the Federation of American Teachers. The union is in the process of organizing graduate students at 25 other US academic institutions.
The strike involves about two thirds of the 2,100 graduate student instructors on the Michigan campus. About half are science and engineering graduate students.

According to the university, they work about 20 hours a week, and earn an average of \$16.34 an hour, making Michigan one of the top US universities in terms of pay and conditions for the instructors. But the students say their monthly income of about $\$ 1,133$ is not enough to make ends meet.

Stephen Arellano, a union spokesman, says pressures on graduate students are intense. "The university likes to refer to us as professionals, but they don't treat us as such," he says. "We do a good job teaching and we should get compensated." The students were demanding a pay increase to $\$ 1,400$ a month.

Some see the events at Michigan as reflecting increasing tension in US research universities. "Graduate students see themselves today as part of a labour group," says one academic lobbyist in Washington. "They don't make enough money, they don't like their conditions, their fellowships [are increasingly] being taken away, they're in debt up to the hilt. This is going to grow."
The issue draws attention to the role of the Association of American Universities (AAU), whose members include most of the major research universities. Although a study last year confirmed the AAU's position that graduate students should primarily be considered as students, it said little about the financial and psychological strains on them.

AAU president Nils Hasselmo says he sees no need for the association to intervene in such conflicts, as universities should deal with militant graduate student unions case by case. But he says the AAU remains interested in the conditions of graduate education.

But others criticize the AAU for not taking a more active role in defending graduate students. One source affiliated to the National Academy of Sciences says: "These students don't want to be United Auto Workers; they want to be students and academics. But they don't want to be walked over, either."

Some predict that postdoctoral students, who are also under economic pressure, may take similar action. And there are also rumblings from adjunct professors, who make even less money than graduate assistants and work longer hours.

WilLepkowski

\section{Japanese emissions plan under fire for relying on nuclear power}

[токуо] Japan's latest plan to tackle global warming has been strongly criticized by environmentalists for its strong dependence on the use of nuclear energy to reduce the nation's emissions of greenhouse gases.

The basic plan on global warming, released last week by the Central Environmental Council of the Environment Agency, details measures for achieving the 6 per cent reduction in greenhouse-gas emissions from 1990 levels by 2008-12 that was agreed by Japan at the Kyoto climate conference in 1997.

The plan, now under consideration in parliament, calls for the promotion of nuclear energy to help reduce the emission of such gases. It proposes that 20 nuclear reactors should be built by 2010 to increase the electricity generated by nuclear power by 50 per cent over its 1997 level.

The plan also includes the development of alternative energy resources such as solar energy. But its main emphasis is on nuclear energy, although it says this should depend on there being adequate safety measures and proper management of radioactive waste.

The plan is based partly on a bill drawn up last year by the agency, which requires both central and prefectural governments to make plans to reduce greenhouse-gas emissions. But it derives mainly from the government's general policy outlines on global warming, also released last year, which indicated that Japan's use of nuclear energy would need to be substantially increased to achieve the planned reduction (see Nature 393, 199 \& 394, 3; 1998).

The first draft of the environment agency's plan focused on alternative energy resources and measures to reduce carbon dioxide emissions in industry, but did not mention nuclear energy. But this was changed after resistance from industrial lobbyists and the Ministry of International Trade and Industry (MITI).

Environmental groups have criticized

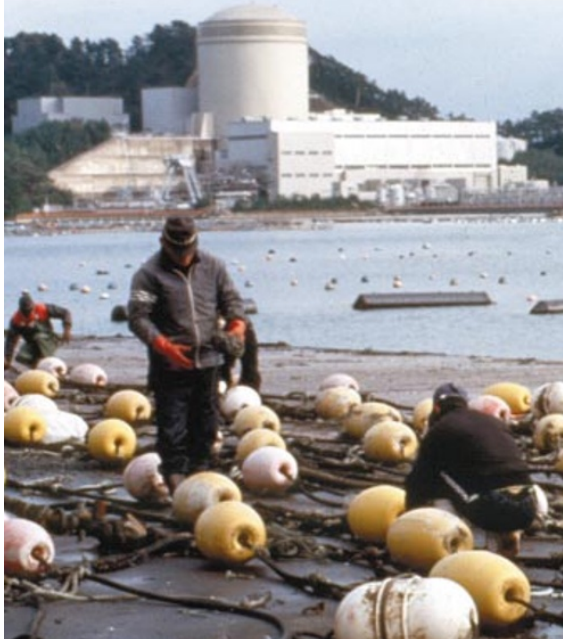

Tarnished: accidents at the Mihama power station and elsewhere have dented nuclear's image.

^ ๑) 1999 Macmillan Magazines Ltd the plan as unrealistic, given the antinuclear mood in Japan following a series of accidents and cover-ups at nuclear facilities.

The electricity industry itself does not seem to want more nuclear reactors. Most electricity companies have frozen plans to build new reactors after strong opposition from local residents. Many are planning to increase the operation time of existing reactors and say that regular safety checks and repairs could double the lifespan of such reactors, normally 30 years.

Although central government cannot build nuclear reactors without the approval of prefectural governments, MITI says it will look again at the problem of radioactive disposal and renew its efforts to increase public support for more nuclear facilities.

But according to Kiko Forum, a federation of more than 100 environmental groups, Japan cannot meet its target for reducing emissions under the current plan without building 20 new reactors.

Mie Asaoka, director-general of Kiko Forum, says: "The problem lies in the fact that [the government] has been overdependent on nuclear energy, and has failed to revise its long-term energy policy."

Asaoka adds that Japan's gross domestic product is declining, with little prospect for immediate recovery. "Perhaps we will not need all the energy the government claims we will," she says.

Asako Saegusa 